\title{
MELLAN DOMESTICERING OCH EXOTISERING.
}

\section{KULTURREFERENSER I ÄLDRE OCH NYARE ÖVERSÄTTNINGAR AV MAJ SJÖWALLS OCH PER WAHLÖÖS KRIMINALROMANER TILL POLSKA}

\author{
GRAŻYNA PIETRZAK-PORWISZ \\ Jagellonian University, Kraków
}

ABSTRACT. The present paper deals with culture-specific items as a translational problem. It is based on two Polish translations of four Swedish books from the famous detective series by Maj Sjöwall and Per Wahlöö.

The aim of the study is to analyze some of the practices employed by two Polish translators against the translation methods proposed by Newmark (1988), Svane (2002) and Ingo (2009). For this purpose a number of highly specific cultural items have been collected and the methods applied by translators have been identified.

The analysis has shown a big difference between translators in dealing with culture-specific items. The first translator, Maria Olszańska, adopts such translation methods as calque translation, hyperonym, functional equivalent, paraphrase and omission. The other translator, Halina Thylwe, prefers transference and calque translation combined with additional explanations, either in the main part of the text or in footnotes. The methods employed by both translators are a result of choosing between global translation strategies domestication and foreignization (Venuti 1995). Domestication, adopted in the older translations, minimizes the strangeness of the Swedish text to the Polish readers, whereas foreignization in the newer translations retains the foreignness of the original.

\section{INLEDNING}

Under översättningsvetenskapens första skede, på 60och 70-talen, diskuterades översättning framför allt som ett lingvistiskt fenomen. Sedan den s.k. kulturella vändningen på 1980-talet, då man började uppfatta översättning inte bara som en form av språklig kommunikation utan 
också som kulturöverföring (bl.a. Vermeer, 1986), har stort utrymme ägnats åt översättningsproblem betingade av kulturskillnader. Bland de intressantaste bidragen kan man nämna Newmark (1988), Baker (1992) och Svane (2002).

Översättaren spelar en mångsidig roll i översättningsprocessen. Å ena sidan uppträder han som talesman för originaltextens författare - han är textens primära mottagare och dess uttolkare och som sådan förväntas han att vara trogen mot originalet. $\AA$ andra sidan fungerar han som språkrör för måltextens presumtiva läsare och förväntas att ta hänsyn till mottagarens behov samt dennes möjligheter att tillägna sig originalets innehåll. Eftersom originalförfattaren och måltextens läsare tillhör olika kulturkretsar, begränsar sig översättarens ansträngningar inte bara till lingvistiska "utbytesoperationer" - han uppträder också som förmedlare mellan kulturer med uppgift att överbrygga kulturdistansen (bl.a. Newmark, 1988; Baker, 1992; Ingo, 2009). Skillnaderna i bakgrundskunskaper hos käll- och måltextläsaren samt frånvaro av vissa begrepp i målkulturens verklighet jämfört med källkulturen vållar ofta problem som måste åtgärdas vid översättning. Eftersom översättningar får leva $\mathrm{i}$ en ny miljö och $\mathrm{i}$ en annorlunda kultursfär, bearbetar översättare källtexterna med tanke på måltexternas mottagare, deras kunskaper och förväntningar. Om källtextläsarens och måltextläsarens kulturerfarenheter skiljer sig väsentligt från varandra, brukar översättare använda sig av olika översättningsstrategier och översättningstekniker, vars mål är att underlätta förståelsen av texter förankrade i andra kulturer.

\section{SYFTE, MATERIAL OCH METOD}

Syftet med föreliggande artikel är att presentera en jämförande analys av återgivning av kulturreferenser i äldre och nyare översättningar av fyra böcker som ingår i Maj Sjöwalls och Per Wahlöös klassiska deckarsvit. Undersökningen omfattar romanerna Den skrattande polisen (1968), Brandbilen som försvann (1969), Den vedervärdige mannen från Säffle (1971) samt Det slutna rummet (1972). De första polska utgåvorna publicerades mellan 1973 och 1990 i översättning av Maria Olszańska. Under åren 20092012 kom en samlad utgåva av alla tio böckerna, varvid de tidigare publicerade romanerna gavs ut i en ny översättning av Halina Thylwe.

Analysmaterialet har valts bland annat därför att de ovannämnda romanerna tillhör de väldigt få svenska texter som har översatts till polska två gånger, vilket erbjuder ett sällan förekommande tillfälle att jämföra olika översättares tillvägagångssätt vid återgivning av samma innehåll.

Maj Sjöwalls och Peter Wahlöös deckarsvit förenar skildringen av brottsfall med ett samhällskritiskt panorama över det samtida Sverige. De undersökta romanerna uppvisar således ett omfattande kulturspecifikt innehåll och rymmer många textpassager i vilka författarna refererar till svenska 
företeelser som kan förefalla främmande för målspråksläsaren. Ur de svenska romanerna har jag excerperat 50 exempel i vilka det åsyftas sådana specifikt svenska fenomen som beteckningar för seder och bruk, helgdagar, maträtter, historiska företeelser, institutioner, lokaliteter o.d. Analysen fokuserar på de lösningar som översättarna har tillämpat vid överföringen av svenska kulturfenomen till polska. Dessa lösningar kallas fortsättningsvis för översättningstekniker. Med översättningsteknik avses översättarens enskilda val av uttryck vid konkreta översättningsproblem (jfr Newmark, 1988:81). Vid kartläggningen av översättningsteknikerna använder jag termer föreslagna $\mathrm{i}$ Newmark (1988), Svane (2002), och Ingo (2009). De i artikeln omtalade översättningsteknikerna omfattar följande fall:

1. direkt återgivande (Svane, 2002:96) när ett uttryck överförs oförändrat från källspråket till målspråket

2. direkt översättning (Svane, 2002:97) då den ursprungliga beteckningen översätts ord för ord eller komponent för komponent

3. tillfogande (i fotnot eller i brödtexten), dvs. tillägg av uttryck som inte finns i originalet (Svane, 2002:98)

4. omskrivning (Newmark, 1988:91) då originalbenämningen ersätts i målspråkstexten med en beskrivning av fenomenet i fråga

5. funktionell motsvarighet (Newmark, 1988:83) då en källspråklig företeelse byts ut mot en målspråklig företeelse som uppfyller samma funktion

6. hyperonym (Ingo, 2009:168) när originalbenämningen ersätts med ett överordnat uttryck

7. utelämnande (Svane, 2002:98) då uttrycket från originaltexten uteblir i måltexten.

Av utrymmesskäl har jag begränsat analysen i föreliggande artikel till fjorton exempel på återgivning av kulturreferenser som jag anser vara representativa för översättarnas tillvägagångssätt. Det händer visserligen att översättarna applicerar likartade lösningar vid återgivning av samma kulturreferenser, men eftersom detta händer sporadiskt, har jag valt att fokusera på de exempel i vilka olika översättningstekniker har tillämpats.

\section{ANALYS AV MATERIALET}

I tabell 1 nedan presenteras originalversionerna samt båda översättningar av de utvalda textstyckena. De äldre och nyare översättningarna benämns som översättning 1 respektive översättning 2. De aktuella kulturreferenserna har strukits under i längre textpartier. Källorna markeras vid ifrågavarande ställen med förkortningar inom parentes (se materialförteckningen). De översatta 
textstyckena har för åskådlighetens skull försetts med tillbakaöversättningar till svenska, angivna inom hakparenteser. Under varje citerat översättningsstycke anges den översättningsteknik som respektive översättare har tillämpat i varje enskilt fall.

\begin{tabular}{|c|c|c|c|}
\hline & Förlagan & $\begin{array}{l}\text { Översättning } 1 \\
\text { (Maria } \\
\text { Olszańska) }\end{array}$ & $\begin{array}{l}\text { Översättning } 2 \\
\text { (Halina Thylwe) }\end{array}$ \\
\hline 1. & $\begin{array}{l}\text { den Gyldene Freden i } \\
\text { Gamla stan } \\
\text { (SW 3:12) }\end{array}$ & $\begin{array}{l}\text { "Złociste Zacisze" } \\
\text { na Starym Mieście } \\
\text { (SW3, O:12) }\end{array}$ & $\begin{array}{l}\text { Złoty Pokój* na Starym } \\
\text { Mieście } \\
\text { *Den Gyldene Freden - } \\
\text { najstarsza restauracja w } \\
\text { Sztokholmie, otwarta w } \\
1722 \text { na Starym } \\
\text { Mieście; nazwa } \\
\text { prawdopodobnie odsyła } \\
\text { do rokowań pokojowych } \\
\text { w Szczecinie w } 1570 \text {. } \\
\text { (SW3,T:14) } \\
\text { [*Den Gyldene Freden - } \\
\text { den äldsta restaurangen i } \\
\text { Stockholm, invigd } 1722 \text { i } \\
\text { Gamla stan; namnet avser } \\
\text { förmodligen } \\
\text { fredsförhandlingarna i } \\
\text { Stettin 1570.] } \\
\text { direkt översättning + } \\
\text { tillfogande i fotnot }\end{array}$ \\
\hline 2. & $\begin{array}{l}\text { Den Gyldene Freden } \\
\text { (SW 4:200) }\end{array}$ & $\begin{array}{l}\text { znana knajpa na } \\
\text { Starym Mieście } \\
(\mathrm{SW} 4, \mathrm{O}: 230)\end{array}$ & $\begin{array}{l}\text { Złoty Pokój* } \\
\text { * Den Gyldene Freden - } \\
\text { najstarsza restauracja w } \\
\text { Sztokholmie, otwarta w } \\
1722 \text { na Starym Mieście; } \\
\text { nazwa prawdopodobnie } \\
\text { odsyła do rokowań } \\
\text { pokojowych w Szczecinie } \\
\text { w } 1570 \text { r. (SW 4, T:240 ) }\end{array}$ \\
\hline
\end{tabular}




\begin{tabular}{|c|c|c|c|}
\hline & & $\begin{array}{l}\text { omskrivning [en } \\
\text { känd krog i Gamla } \\
\text { stan] }\end{array}$ & $\begin{array}{l}\text { [*Den Gyldene Freden - } \\
\text { den äldsta restaurangen i } \\
\text { Stockholm, invigd } 1722 \text { i } \\
\text { Gamla stan; namnet avser } \\
\text { förmodligen } \\
\text { fredsförhandlingarna i } \\
\text { Stettin 1570.] } \\
\text { direkt översättning + } \\
\text { tillfogande i fotnot }\end{array}$ \\
\hline 3. & $\begin{array}{l}\text { [Malm] Hade suttit på } \\
\text { Beckis flera gånger. } \\
\text { (SW2:68) }\end{array}$ & $\begin{array}{l}\begin{array}{l}\text { Parę razy } \\
\text { przebywał w } \\
\text { psychiatrycznym. }\end{array} \\
\text { (SW2, O:74) }\end{array}$ & $\begin{array}{l}\text { Kilka razy był w Beckis*. } \\
\text { *Szpital psychiatryczny w } \\
\text { Beckomberdze, w } \\
\text { zachodnim Sztokholmie } \\
\text { (1935-1995), w poł. XX } \\
\text { w. jeden z największych } \\
\text { w Europie, symbol } \\
\text { wariatkowa, od } 2008 \\
\text { specjalizuje się w } \\
\text { chorobach geriatrycznych. } \\
\text { (SW2, T:76) } \\
\text { [*Mentalsjukhus i } \\
\text { Beckomberga i västra } \\
\text { Stockholm (1935-1995), i } \\
\text { mitten av 1900-talet ett av } \\
\text { de största i Europa, en } \\
\text { symbol för sinnessjukhus, } \\
\text { specialiserar sig sedan } \\
\text { 2008 på geriatrisk vård.] } \\
\text { direkt återgivande + } \\
\text { tillfogande i fotnot }\end{array}$ \\
\hline 4. & $\begin{array}{l}\text { Han }[\ldots] \text { steg av vid } \\
\text { Handelshögskolan. } \\
\text { (SW 4:214) }\end{array}$ & $\begin{array}{l}{[\ldots] \text { wysiadł przy }} \\
\text { Wyższej Szkole } \\
\text { Handlowej. } \\
\text { (SW4, O:255) }\end{array}$ & $\begin{array}{l}{[\ldots] \text { dotarł w okolice }} \\
\text { Handelshögskolan*. } \\
\text { *Wyższa Szkoła } \\
\text { Ekonomiczna. (SW4, T:256) } \\
\text { [*Handelshögskolan] }\end{array}$ \\
\hline
\end{tabular}




\begin{tabular}{|c|c|c|c|}
\hline & & $\begin{array}{l}\text { direkt } \\
\text { översättning }\end{array}$ & $\begin{array}{l}\text { direkt återgivande + } \\
\text { direkt översättning } \\
\text { i fotnot }\end{array}$ \\
\hline 5. & $\begin{array}{l}\text { Rätt långt ute vid } \\
\text { Stadsgården låg en } \\
\text { gammal lastångare... } \\
\text { (SW3:47) }\end{array}$ & $\begin{array}{l}\text { Dosyć daleko w } \\
\text { głębi } \\
\text { zakotwiczony był } \\
\text { stary } \\
\text { frachtowiec... } \\
\text { (SW3, O:46) } \\
\text { [Rätt långt ute låg } \\
\text { en gammal } \\
\text { lastångare...] } \\
\text { utelämnande }\end{array}$ & $\begin{array}{l}\text { Dosyć daleko, przy } \\
\text { Stadsgården*, cumował } \\
\text { stary parowiec... } \\
\text { *Przystań Miejska. (SW3, } \\
\text { T:56) } \\
\text { [*Stadsgården] } \\
\text { direkt återgivande + } \\
\text { direkt översättning i } \\
\text { fotnot }\end{array}$ \\
\hline 6. & $\begin{array}{l}\text { I en korg bredvid spisen } \\
\text { låg en bunt tidningar; } \\
\text { Dagens Nyheter, Vi, Ny } \\
\text { Dag och Metallarbetaren. } \\
\text { (SW 4:38) }\end{array}$ & $\begin{array}{l}\text { W wiklinowym } \\
\text { stojaku przy } \\
\text { kominku leżał plik } \\
\text { gazet. Nowiny } \\
\text { Dnia, My, Nowy } \\
\frac{\text { Dzień i }}{\text { Metalowiec. }} \\
\text { (SW 4, O:45) }\end{array}$ & $\begin{array}{l}\text { W koszu obok kominka } \\
\text { sterta gazet: „,Dagens } \\
\text { Nyheter”, „Vi”*, „Ny } \\
\text { Dag”**i } \\
\text { „Metallarbetaren”***. } \\
\text { *,Vi” (My) - szwedzki } \\
\text { tygodnik społeczno- } \\
\text { kulturalny, obecny na } \\
\text { rynku od 1913 r. } \\
\text { ** „Ny Dag” (Nowy } \\
\text { Dzień) - szwedzki } \\
\text { dziennik komunistyczny } \\
\text { ukazujący się w latach } \\
\text { 1930-1990, w 1974-1982 } \\
\text { jako ,Arbetartidningen Ny } \\
\text { Dag” (Dziennik } \\
\text { robotniczy Nowy Dzień). } \\
\text { ***,Metallarbetaren” } \\
\text { pismo branżowe } \\
\text { szwedzkich metalowców, } \\
\text { od 1997 r. ukazuje się } \\
\text { jako „Dagens arbete”. } \\
\text { (SW 4, T:47) }\end{array}$ \\
\hline
\end{tabular}




\begin{tabular}{|c|c|c|c|}
\hline & & $\begin{array}{l}\text { direkt } \\
\text { översättning }\end{array}$ & $\begin{array}{l}\text { [*,,Vi”- en svensk } \\
\text { kulturinriktad } \\
\text { veckotidning verksam } \\
\text { sedan 1913. } \\
\text { **, „Ny Dag”- en svensk } \\
\text { kommunistisk dagstidning } \\
\text { verksam under åren 1930- } \\
\text { 1990, mellan } 1974 \text { och } \\
\text { 1982 som } \\
\text { „Arbetartidningen Ny } \\
\text { Dag”. } \\
\text { ***,,Metallarbetaren”- } \\
\text { medlemstidning för } \\
\text { svenska industriarbetare, } \\
\text { sedan 1997 utgiven som } \\
\text { „Dagens arbete”.] } \\
\text { direkt återgivande + } \\
\text { tillfogande i fotnot }\end{array}$ \\
\hline 7. & $\begin{array}{l}\text { Ett par berusade } \\
\text { ynglingar, som kom upp } \\
\text { ur Drakens gränd... } \\
\text { (SW3:14) }\end{array}$ & $\begin{array}{l}\text { Z zaułka wypadło } \\
\text { kilku pijanych } \\
\text { młodzieńców... } \\
\text { (SW3, O:14) } \\
\text { hyperonym } \\
\text { [gränd] }\end{array}$ & $\begin{array}{l}\text { Z Drakens gränd } \\
\text { wytoczyło się kilku } \\
\text { zawianych wyrostków. } \\
(\mathrm{SW} 3, \mathrm{~T}: 16) \\
\text { direkt återgivande }\end{array}$ \\
\hline 8. & $\begin{array}{l}\text { Den här kvällen hade han } \\
\text { suttit på Pilen vid } \\
\text { Bryggargagatan... } \\
\text { (SW1:109) }\end{array}$ & $\begin{array}{l}\text { Tego wieczoru był } \\
\text { w ,Strzale” przy } \\
\text { Bryggargatan... } \\
\text { (SW 1, O: 145) } \\
\text { direkt } \\
\text { översättning }\end{array}$ & $\begin{array}{l}\text { Ten wieczór przesiedział } \\
\text { w restauracji Pilen na } \\
\text { Bryggargatan... (SW 1, } \\
\text { T:115) } \\
\text { [restaurangen Pilen] } \\
\text { direkt återgivande + } \\
\text { tillfogande (hyperonym) } \\
\text { i brödtext }\end{array}$ \\
\hline 9. & $\begin{array}{l}\text { Han for raka vägen till } \\
\text { Sturebadet... } \\
(\text { SW2:80) }\end{array}$ & $\begin{array}{l}\text { Pojechał wprost do } \\
\text { kapieliska... } \\
\text { (SW2, O:87) }\end{array}$ & $\begin{array}{l}\text { Czym prędzej pojechał do } \\
\text { Sturebadet*... } \\
\text { * Łaźnia z tradycjami, }\end{array}$ \\
\hline
\end{tabular}




\begin{tabular}{|c|c|c|c|}
\hline & & $\begin{array}{l}\text { hyperonym } \\
\text { [badet] }\end{array}$ & $\begin{array}{l}\text { otwarta w Sztokholmie } \\
\text { przy Sturegatan w } 1885 \\
\text { dzięki inicjatywie lekarza } \\
\text { C. Curmana, w } 1902 \\
\text { powiększona o kryty } \\
\text { basen, po pożarze w } 1985 \\
\text { odbudowana, obecnie } \\
\text { jedna z atrakcji centrum } \\
\text { handlowego. } \\
\text { (SW 2, T:90) } \\
\text { [*Ett bad med långa anor, } \\
\text { invigt vid Sturegatan } 1885 \\
\text { på initiativ av läkaren C. } \\
\text { Curman; 1902 utökat med } \\
\text { en simhall; återuppbyggt } \\
\text { efter branden 1985; för } \\
\text { närvarande en av } \\
\text { attraktionerna i ett } \\
\text { shoppingcentrum.] } \\
\text { direkt återgivande + } \\
\text { tillfogande i fotnot }\end{array}$ \\
\hline 10. & prinsesstårta (SW3:167) & $\begin{array}{l}\text { tort (SW3, O:164) } \\
\text { hyperonym [tårta] }\end{array}$ & $\begin{array}{l}\text { tort marcepanowy (SW3, } \\
\text { T:200) } \\
\text { omskrivning } \\
\text { [marsipantårta] }\end{array}$ \\
\hline 11. & $\begin{array}{l}\text { Han la upp en portion } \\
\text { lutfisk. } \\
\text { (SW1:181) }\end{array}$ & $\begin{array}{l}\text { Nałożył sobie } \\
\text { porcję suszonego } \\
\text { sztokfisza } \\
\underline{\text { moczonego w }} \\
\underline{\text { mleku. }} \\
\text { (SW1, O:238) }\end{array}$ & $\begin{array}{l}\text { Nałożył sobie porcję } \\
\text { lutfisk*... } \\
\text { *Szwedzka potrawa } \\
\text { wigilijna - suszona molwa } \\
\text { lub czarniak, moczone } \\
\text { przez parę tygodni w } \\
\text { wodzie z ługiem, } \\
\text { przyprawione solą i dużą } \\
\text { ilością pieprzu, zwykle } \\
\text { podawane z beszamelem. } \\
\text { (SW1, T:189) } \\
\text { [*Svensk julrätt - torkad } \\
\text { långa eller gråsej; blötlagd }\end{array}$ \\
\hline
\end{tabular}




\begin{tabular}{|c|c|c|c|}
\hline & & $\begin{array}{l}\text { omskrivning } \\
\text { [torrfisk uppblött i } \\
\text { mjölk] }\end{array}$ & $\begin{array}{l}\text { under några veckor i } \\
\text { vatten med lut; kryddad } \\
\text { med stora mängder salt } \\
\text { och peppar; serveras } \\
\text { vanligen med vitsås.] } \\
\text { direkt återgivande + } \\
\text { tillfogande i fotnot }\end{array}$ \\
\hline 12. & $\begin{array}{l}\text { isterband med stuvad } \\
\text { potatis } \\
(\mathrm{SW} 4: 164)\end{array}$ & $\begin{array}{l}\text { bekon z duszonymi } \\
\text { ziemniakami } \\
\text { (SW4, O:197) } \\
\text { funktionell } \\
\text { motsvarighet } \\
\text { [bacon] }\end{array}$ & $\begin{array}{l}\text { isterband* z ziemniakami } \\
\text { pod beszamelem } \\
\text { *Kiełbasa z wieprzowiny, } \\
\text { kaszy jęczmiennej i } \\
\text { ziemniaków. } \\
\text { (SW4, T:200) } \\
\text { [*Korv gjord på fläskkött, } \\
\text { korngryn och potatis.] } \\
\text { direkt återgivande + } \\
\text { tillfogande i fotnot }\end{array}$ \\
\hline 13. & $\begin{array}{l}\text { Om jag hade fått ställa } \\
\text { upp i en sån där tävling, } \\
\text { tiotusenkronorsfrågan... } \\
\text { (SW1:183-4) }\end{array}$ & $\begin{array}{l}\text { Gdybym stanął do } \\
\text { zawodów, wielka } \\
\text { gra... } \\
\text { (SW1, O:241) }\end{array}$ & $\begin{array}{l}\text { Gdybym wziął udział w } \\
\text { Pytaniu za dziesieć tysięcy } \\
\text { koron*... } \\
\text { *Tiotusenkronorsfrågan } \\
\text { albo Kvitt eller dubbelt - } \\
\text { bardzo popularny } \\
\text { teleturniej, format amer. } \\
64 \text { 000 Dollars Question, } \\
\text { pierwsza emisja w } \\
\text { szwedzkiej TV } 12 \\
\text { stycznia 1957; podobny } \\
\text { do Wielkiej gry. } \\
\text { (SW1, T:191) } \\
\text { [*Tiotusenkronorsfrågan } \\
\text { eller Kvitt eller dubbelt - } \\
\text { en mycket populär } \\
\text { frågesport, sändes för } \\
\text { första gången den } 12 \\
\text { januari 1957; } \\
\text { programformatet efter det }\end{array}$ \\
\hline
\end{tabular}




\begin{tabular}{|c|c|c|c|}
\hline & & $\begin{array}{l}\text { funktionell } \\
\text { motsvarighet } \\
\text { ["wielka gra" - } \\
\text { namnet på en känd } \\
\text { polsk frågesport] }\end{array}$ & $\begin{array}{l}\text { amerikanska } 64000 \\
\text { Dollars Question, liknar } \\
\text { Wielka gra.] } \\
\text { direkt översättning + } \\
\text { tillfogande i fotnot }\end{array}$ \\
\hline 14. & $\begin{array}{l}\text { Ibland undrade hans } \\
\text { slutkörda medarbetare, } \\
\text { om det kanske rent av var } \\
\text { han själv [Bulldozer } \\
\text { Olsson] som var direktör i } \\
\text { det mycket omtalade } \mathrm{AB} \\
\text { Svenska Brott. } \\
\text { (SW 4:46) }\end{array}$ & $\begin{array}{l}\text { Czasami jego } \\
\text { padający z } \\
\text { wyczerpania } \\
\text { współpracownicy } \\
\text { zastanawiali się, } \\
\text { czy może nie on } \\
\text { sam po prostu jest } \\
\text { dyrektorem tak } \\
\text { często } \\
\text { wymienianej } \\
\text { Spółki Akcyjnej } \\
\text { Szwedzkiej } \\
\text { Zbrodni. } \\
\text { (SW 4, O:54) }\end{array}$ & $\begin{array}{l}\text { Jego ledwie żywi } \\
\text { współpracownicy } \\
\text { zastanawiali się czasem, } \\
\text { czy to przypadkiem nie on } \\
\text { jest prezesem często } \\
\text { przywoływanej firmy AB } \\
\text { Svenska Brott*. } \\
\text { *AB Svenska Brott } \\
\text { (Szwedzkie Przestępstwa } \\
\text { SA) - nazwa ukuta przez } \\
\text { szwedzkie media w latach } \\
\text { 60. XX w. odsyłająca do } \\
\text { gangu legendarnych, } \\
\text { rodzimych kryminalistów. } \\
\text { (SW 4, T:58) } \\
\text { [*AB Svenska Brott - } \\
\text { namn myntat på 1960- } \\
\text { talet av svenska } \\
\text { massmedia, syftande på } \\
\text { ett känt svenskt kriminellt } \\
\text { gäng.] }\end{array}$ \\
\hline & & $\begin{array}{l}\text { direkt } \\
\text { översättning }\end{array}$ & $\begin{array}{l}\text { direkt återgivande }+ \\
\text { tillfogande i brödtext }+ \\
\text { tillfogande i fotnot }\end{array}$ \\
\hline
\end{tabular}

(Tab. 1) Kulturreferenser i översättningar av Maj Sjöwalls och Per Wahlöös kriminalromaner till polska

Det framgår av det i tabellen anförda undersökningsmaterialet att översättarna har valt olika lösningar vid återgivningen av kulturreferenserna. Den första översättaren har använt följande tekniker: direkt översättning (fem gånger), hyperonym (fyra gånger), funktionell motsvarighet (två gånger), omskrivning (två gånger), utelämnande (en gång), medan den andra 
översättaren har tillämpat: direkt återgivande åtföljt av tillfogande i fotnot eller i brödtexten (sju gånger), direkt översättning jämte tillfogande $i$ fotnot (tre gånger), direkt återgivande åtföljt av direkt översättning i fotnot (två gånger), direkt återgivande (en gång), omskrivning (en gång).

I nio av de anförda exemplen förekommer det egennamn, dvs. benämningar på olika lokaliteter i Stockholm (ex. 1 - 5, 4-9) samt titlar på svenska tidningar (6). Dessa namn spelar ingen framträdande roll i sina sammanhang men uppfyller en viktig funktion med hänsyn till originaltexterna sedda i ett mera globalt perspektiv: genom att hänvisa till svenska fenomen bidrar de till texternas verklighetsförankring och ger en äkta lokalfärg åt framställningen. Den första översättaren tillämpar vid återgivningen av egennamnen framför allt direkt översättning (ex. 1, 4, 6, 8) som resulterar i att den semantiska innebörden hos de översatta namnen blir klar för läsaren men texten förlorar samtidigt sin lokalfärg. I tre av fallen har egennamnen i den första översättningen ersatts med hyperonymer (ex. 3, 7,9) och i ett fall med omskrivning (ex. 2) - båda teknikerna leder till att texten berövas sin lokalfärg. Därutöver har den första översättaren tillämpat utelämnande (ex. 5) som självklart resulterar i en betydelseförlust.

De lösningar som den andra översättaren har använt sig av vid återgivningen av egennamnen utgörs i de flesta fall av direkt återgivande (ex. 3 - 9) samt av direkt översättning $(1,2)$. Utom i ett av fallen (7) kombineras dessa lösningar med direkt översättning i fotnot (ex. 4, 5) eller med tillfogande, både i fotnot $(1,2,3,6,9)$ och i brödtexten (8). Dessa åtgärder resulterar $i$ att originalnamnen antingen lämnas oförändrade $i$ den löpande texten eller finns med i förklaringarna utplacerade $\mathrm{i}$ fotnoterna. Tack vare dessa lösningar bevarar texten sin lokala förankring. Man får dock konstatera att de utförliga fotnoterna samtidigt också medför betydelsetillskott som i många fall får bedömas som överflödiga. Vid ett omfattande notsystem uppstår det risk att den information som är viktigast i sammanhanget försvinner bland de övriga uppgifterna. En effektiv lösning tack vare vilken man både kan behålla lokalfärgen och klargöra innehållet hos det omtalade begreppet för läsaren är att kombinera direkt återgivande med tillfogande av en förklarande hyperonym i brödtexten - som den andra översättaren har gjort i exempel (8). Även om det främmande namnet Pilen är helt obekant, förses läsaren med information tack vare vilken han förstår vilken typ av fenomen som åsyftas.

Tre av de analyserade textstyckena (ex. 10,11 och 12) innehåller namn på maträtter som inte existerar i målkulturen - prinsesstårta, lutfisk samt isterband. Den första översättaren har tillämpat tre olika lösningar: prinsesstårta har ersatts med hyperonymen "tårta", lutfisk med omskrivningen "torrfisk uppblött i mjölk" och isterband har fătt en funktionell motsvarighet det har bytts ut mot bacon som till skillnad från originalbegreppet blir igenkänt av mottagaren. Nackdelen med dessa lösningar är att det uppkommer 
betydelseförskjutningar och att verklighetsförankringen blir lidande. Den andra översättaren har däremot använt sig av en omskrivning och i de övriga två fallen av direkt återgivande jämte tillfoganden i fotnoter där hon förklarar vilka ingredienser maträtterna består av, hur de tillagas och serveras. På det sättet har hon gjort läsaren uppmärksam på kulturskillnaderna.

I exempel (13) där frågesporten tiotusenkronorsfrågan omnämns har den första översättaren valt en funktionell motsvarighet - hon har bytt ut det okända svenska begreppet mot en polsk frågesport som måltextläsaren känner igen. Den andra översättaren har i detta fall tillämpat direkt återgivande och tillfogande i fotnot där hon redogör för programmets historia och innebörd. Den första översättaren raderar därmed det främmande begreppet medan den andra understryker kulturskillnaden genom sitt val.

I det sista exemplet (14) omtalas en åklagare vars ovanliga energi och iver i bekämpningen av brottslighet gör att hans medarbetare misstänker att han själv ligger bakom en hel del grova brott för att senare kunna utreda dem och skryta med sina prestationer. Den ironiska kommentaren anknyter till det kriminella gäng som på 1960-talet döptes till "AB Svenska Brott" av massmedia. Originalbeteckningen väcker således specifika konnotationer hos källtextens läsare. I den första översättningen har uttrycket överförts direkt, vilket resulterar i att måltextläsaren har svårt att förstå sammanhanget. Översättaren gör inget försök att förmedla den bakomliggande kontexten med konsekvensen att en viktig betydelsedimension går förlorad. Den andra översättaren lägger till hyperonymen "firma" till originalbenämningen samt förklarar dess uppkomst och betydelse i fotnoten, vilket gör att måltextläsaren får den information som behövs för att förstå sammanhanget.

\section{AVSLUTANDE DISKUSSION}

De av översättarna föredragna översättningsteknikerna vid återgivning av kulturreferenser kan ses i relation till mer globala översättningsstrategier. Med översättningsstrategi avses översättarens övergripande förhållningssätt mot källtexten och mot måltextens presumtiva läsare som påverkar valet av översättningstekniker (Lundquist, 1997:30, jfr Newmark, 1988 som i detta sammanhang använder termen "translation method"). Valet av översättningstekniker är således en följd av de antagna översättningsstrategierna och återspeglar översättarnas allmänna inställning till den översatta texten (Newmark, 1988:81). Vid åtgärder inriktade på återgivning av kulturspecifika referenser, brukar man diskutera två grundstrategier som beskrivs med hjälp av termer myntade av Lawrence Venuti: domesticering respektive exotisering (Venuti, 1995:20). Venuti inspirerades i valet av dessa termer av Friedrich Schleiermacher (1998) som skiljde mellan två huvudmetoder att översätta - genom att antingen föra texten 
mot läsaren, vilket motsvarar domesticering - eller genom att föra läsaren mot texten, vilket är liktydigt med exotisering. I det första fallet strävar översättaren efter att skapa en välfungerande, smidig text som låter som ett original på målspråket och avlägsnar därvid element som åsyftar företeelser som kan uppfattas som främmande i målspråkskulturen (en målspråksanpassad strategi). I det andra fallet framhäver översättaren de främmande inslagen och visar genom sina val av uttryck att texten kommer från en annan kultursfär (en källspråksanpassad strategi).

Analysen av det undersökta materialet visar tydligt att de båda översättarna uppvisar olika förhållningssätt mot källtexten och mot måltextens läsare. Båda tar hänsyn till den tilltänkte läsarens bakgrundskunskaper om källkulturen men de uppfattar dennes behov på skilda sätt, varför de tillämpar olika strategier och väljer olika översättningstekniker.

De äldre översättningarna representerar den domesticerande strategin. Översättarens ansträngningar är inriktade på att måltextens läsare ska känna sig hemmastadd i den översatta texten utan att behöva reflektera över främmande kulturelement. Egennamn översätts eller parafraseras och översättaren förser inte läsaren med uppgifter som är nödvändiga för förståelsen av de kontexter som är självklara för originalets läsare. Den flitiga användningen av hyperonymer resulterar i betydelseförluster och gör att texten förlorar sin lokala förankring. Dessutom utelämnas inte bara enstaka ord och uttryck utan också hela textpassager som innehåller kulturspecifika referenser. I översättningen av romanen Det slutna rummet har två längre stycken tagits bort. Det första utgör en kritisk kommentar till polisreformen och i det andra diskuteras Artur Lundkvists politiska åsikter. Dessa textpassager har tydligen bedömts som ointressanta för målspråksläsaren och har inte blivit återgivna $\mathrm{i}$ måltexten. De tekniker som översättaren har valt resulterar således i olika slags reduktioner som gör att måltextläsaren många gånger berövas den information som funnits i originaltexten.

De nyare översättningarna utgör däremot exempel på den exotiserande strategin. Den andra översättaren är mycket mån om att framhäva de främmande inslagen och göra läsaren uppmärksam på skillnaderna mellan käll- och målkulturen, varför kulturspecifika element ofta behålls i originalform samt förses med förklarande tillägg, antingen i brödtexten eller i fotnoter. Om översättaren väljer direkt översättning, sätter hon samtidigt ut originalbenämningar $\mathrm{i}$ åtföljande fotnoter. I de nyare översättningarna förekommer inga utelämningar och användningen av hyperonymer är ytterst sparsam. Översättaren strävar efter att utjämna skillnaderna i bakgrundskunskaper mellan källtextens läsare och måltextens läsare, varför hon ofta kombinerar olika tekniker som i förening ger större möjligheter att förmedla innebörden hos främmande kulturreferenser. Samtidigt kan man undra om den andra översättaren inte har gått för långt i sina ansträngningar att 
bibringa läsaren det kulturspecifika innehållet eftersom hon många gånger förser honom med mycket detaljerad information som inte är relevant $\mathrm{i}$ sammanhanget och som kan störa flytet i texten.

De strategier som översättarna har valt vid återgivning av kulturreferenser i Sjöwalls och Wahlöös romaner representerar motpoler i översättarnas attityder mot originaltexten och den tilltänkte läsaren. Huvudfunktionen med den domesticerande strategin är att göra den översatta texten flytande och förståelig (jfr Venuti, 1995:21), vilket sker på bekostnad av precision och lokalfärg. Den exotiserande strategin går ut på att bevara så mycket som möjligt av de källkulturella förhållandena men det finns risk för att översättarens iver i stället för att underlätta förståelsen försvårar läsningen av måltexten. Man kan därvid fråga sig hur långt man kan gå i appliceringen av de båda strategierna och om det är lämpligt att enbart hålla sig till antingen exotiserande eller domesticerande lösningar. Frågan är naturligtvis inte lätt att besvara eftersom måltextens läsare har olika förutsättningar och preferenser, de kan behöva översättarens guidning genom den främmande kulturen i olika hög grad. Det vore säkert optimalt att försöka hitta den gyllene vägen tack vare vilken man skulle kunna behålla balansen mellan det igenkända och det främmande i de översatta texterna men att utstaka allmänna riktlinjer för hur detta skulle kunna gå till verkar vara en omöjlig uppgift. Valet av översättningsstrategi och översättningstekniker är i sista hand avhängigt den specifika översättningssituationen och översättarna får överväga vilka lösningar som fungerar bäst i varje enskilt fall.

En fråga som infinner sig efter genomgången av undersökningsmaterialet är vilka faktorer som ligger bakom översättarnas val av respektive källspråksinriktad och målspråksinriktad översättningsstrategi. Dessa val kan dels bero på översättarnas egna preferenser och återspegla deras individuella översättarstil (se t.ex. Dimitrova, 2013), dels på översättarnas anpassning till de översättningsnormer som vid tidpunkterna för publicering av översättningarna rådde på bokmarknaden (se bl.a. Toury, 1995). De analyserade måltexterna är tillkomna med 20-30 års mellanrum, vilket innebär att de har fungerat $i$ olika litterära och kulturella kontexter där översättningsnormerna kan ha sett olika ut både vad gäller den generella synen på vad som är en god översättning och vad gäller behandlingen av kulturreferenser. Utifrån det undersökta materialet är det dock knappast möjligt att dra några generella slutsatser om i vilken utsträckning översättarnas val har påverkats av deras egna preferenser eller av de rådande översättningsnormerna.

Resultaten framtagna genom denna undersökning skulle kunna utgöra grund för fortsatt forskning kring översättningsstrategier och översättningstekniker, inte bara med avseende på återgivning av kulturreferenser. Man skulle kunna utvidga materialet med fler texter 
tillkomna vid olika tidpunkter, antingen översatta av samma eller av olika översättare, för att jämföra hur olika textelement har hanterats vid överföring till målspråket. Utifrån dylika studier skulle en diskussion kunna föras om översättarstil, översättningsnormer och andra faktorer som kan styra översättarnas val.

\section{MATERIAL}

SW1 = Sjöwall, M., Wahlöö, P. (1990) [1967]. Den skrattande polisen. Stockholm: Bokförlaget PAN /Norstedts.

SW1, O = Sjöwall, M., Wahlöö, P. (1973). Śmiejący się policjant. Övers. M. Olszańska. Warszawa: Czytelnik.

SW1, T = Sjöwall, M., Wahlöö, P. (2010). Śmiejacy się policjant. Övers. H. Thylwe. Warszawa: Wydawnictwo AMBER.

SW 2 = Sjöwall, M., Wahlöö, P. (1998) [1967]. Brandbilen som försvann. Stockholm: Bokförlaget PAN /Norstedts.

SW 2, O = Sjöwall, M., Wahlöö, P. (1990). Jak kamień w wodę. Övers. M. Olszańska. Poznań: Wydawnictwo Poznańskie.

SW 2, T = Sjöwall, M., Wahlöö, P. (2010). Wóz strażacki, który zniknąt. Övers. H. Thylwe. Warszawa: Wydawnictwo AMBER.

SW3 = Sjöwall, M., Wahlöö, P. (1990) [1967]. Den vedervärdige mannen från Säffle. Stockholm: Bokförlaget PAN /Norstedts.

SW3, O = Sjöwall, M., Wahlöö, P. (1976). Cztowiek z Säffle. Övers. M. Olszańska. Poznań: Wydawnictwo Poznańskie.

SW3, T = Sjöwall, M., Wahlöö, P. (2011). Twardziel z Säffle. Övers. H. Thylwe. Warszawa: Wydawnictwo AMBER.

SW4 = Sjöwall, M., Wahlöö, P. (1973) [1972]. Det slutna rummet. Stockholm: Bokförlaget PAN /Norstedts.

SW4, O = Sjöwall, M., Wahlöö, P. (1990) [1980]. Zamknięty pokój. Övers. M. Olszańska. Poznań: Wydawnictwo Poznańskie.

SW4, T = Sjöwall, M., Wahlöö, P. (2011). Zamknięty pokój. Övers. H. Thylwe. Warszawa: Wydawnictwo AMBER.

\section{LITTERATUR}

Baker, M. (1992). In Other Words: A Coursebook on Translation. London \& New York: Routledge.

Dimitrova, B.E. (2013). Lexikala val som ett drag i översättarstil. En studie av två bulgariska noveller i svensk översättning. I: E. Bladh, M.P. Ängsal (red.), Översättning, stil och lingvistiska metoder (s. 55-74). Göteborg: Institutionen för språk och litteratur, Göteborgs universitet.

Ingo, R. (2009). Konsten att översätta. Översättandets didaktik och praktik. Lund: Studentlitteratur.

Lundquist, L. (1997) [1994]. Oversattelse: problemer og strategier, set i tekstlingvistisk og pragmatisk perspektiv. Frederiksberg: Samfundslitteratur.

Newmark, P. (1988). A Textbook of Translation. New York: Prentice Hall. 
Schleiermacher, F. (1998) [1813]. Om de olika metoderna att översätta. Övers. L. Bjurman. I: L. Kleberg (red.), Med andra ord (s. 115-130). Stockholm: Natur och Kultur.

Svane, B. (2002). Hur översätter man verkligheten? (Rapporter från forskningsprogrammet Översättning och tolkning som språk- och kulturmöte 1.) Uppsala: Uppsala universitet.

Toury, G. (1995). Descriptive Translation Studies and beyond. Amsterdam \& Philadelphia: John Benjamins Publishing Company.

Venuti, L. (1995). The Translator's Invisibility: A History of Translation. London \& New York: Routledge.

Vermeer, H.J. (1986). Übersetzen als kultureller Transfer. I: M. Snell-Hornby (red.), Übersetzungwissenschaft. Eine Neuorientierung. Zur Integration von Theorie und Praxis (s. 30-53). Tübingen: Francke Verlag.

\section{Grażyna Pietrzak-Porwisz}

Uniwersytet Jagielloński

Zakład Filologii Szwedzkiej

al. Mickiewicza 9a

31-120 Kraków

Poland

grazyna.pietrzak-porwisz@uj.edu.pl 